
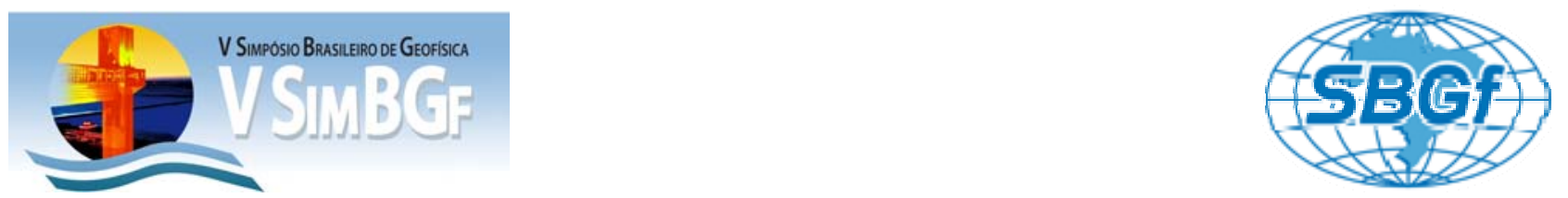

\title{
Magnetic Anomalies in the Structural Provinces of Tocantins and San Francisco of Central Brazil: Results from Spectral Analysis of Aeromagnetic Data
}

\author{
Guimarães, S.N.P. ${ }^{1}$ Ravat D. ${ }^{2}$ and Hamza, V.M. ${ }^{1}$ \\ ${ }^{1}$ National Observatory - ON/MCTI - Department of Geophysics \\ ${ }^{2}$ University of Kentucky - Department of Earth \& Environmental Sciences.
}

Copyright 2012, SBGf - Sociedade Brasileira de Geofísica

Este texto foi preparado para a apresentação no V Simpósio Brasileiro de Geofísica, Salvador, 27 a 29 de novembro de 2012. Seu conteúdo foi revisado pelo Comitế Técnico do V SimBGf, mas não necessariamente representa a opinião da SBGf ou de seus associados. É proibida a reprodução total ou parcial deste material para propósitos comerciais sem prévia autorização da SBGf.

\begin{abstract}
In this work we report progress obtained in understanding the thermal structure of crust in two geologic provinces of central Brazil: Tocantins (eastern segment) and San Francisco. The study is based on spectral analysis of aeromagnetic data, obtained in 12 different surveys. The technique employed in data analysis is the scaled spectral slope method (Bhattacharyya and Leu, 1975, 1977). It allows determination of the depths to top and bottom of magnetized crust.

According to the model results the depths to the bottom of magnetic sources fall in the range of $30-45 \mathrm{~km}$ in the province of Tocantins while it is in the range of $40-60 \mathrm{~km}$ in the province of San Francisco. The differences in depth values are considered indications of a systematic change in the deep thermal structures of these provinces.
\end{abstract}

\section{Introduction}

A number of geologic and geophysical investigations have been carried out over the last few decades for understanding the crustal structure of the continental interior of the Brazilian platform. However, very few results have been reported concerning the thermal field of the Brazilian highlands. In the present work we make use of aeromagnetic and geothermal data sets in outlining the thermal structure of the Brazilian Highlands. The purpose has been to map the thickness of the magnetized crust, defined on the basis of depth of Curie temperatures.

The area selected for the purposes of the present work is limited to the structural provinces of Tocantins (eastern segment) and San Francisco (PSF).

\section{Regional Geology and Geophysics}

Two different structural units occur in the study area: Tocantins Province and the San Francisco Province. The Tocantins province includes meta-sedimentary belts (Araguaia, Uruaçu and Brasília) of proterozoic age and granitic-gneissic-granulitic basement blocks (Goias Median Massiff) of archean age. Also found are volcanosedimentary sequences associated with crustal accretion and island arc environments of neo-Proterozoic age. The province of San Francisco is composed of geologic structures with ages varying from mesoarquean to paleoProterozoic. It includes Mineiro belt and the metamorphic complex of Minas (Bonfim, Belo Horizonte e Campo Belo) in the south and Itabuna-Salvador-Curaçá belt (that includes Gavião, Jequié and Serrinha blocks) in the north. Regional geophysical studies carried out in this area include gravity, magnetic, seismic and geothermal. Results of deep seismic sounding (França, 2003; Assumpção et al, 2004; Berrocal et al, 2004) have been interpreted as indicating crustal thicknesses in the range of 30 to $40 \mathrm{~km}$. Heat flow values are found to fall in the range of 30 to $70 \mathrm{~mW} / \mathrm{m}^{2}$ (Vitorello et al, 1980; Hamza and Muñoz, 1996; Alexandrino and Hamza, 2008). Airborne geophysical surveys have been carried out in several localities in the south and central regions of Brazil. The aeromagnetic surveys cover nearly $80 \%$ of the study area, locations of which are indicated in the map of Figure (1).

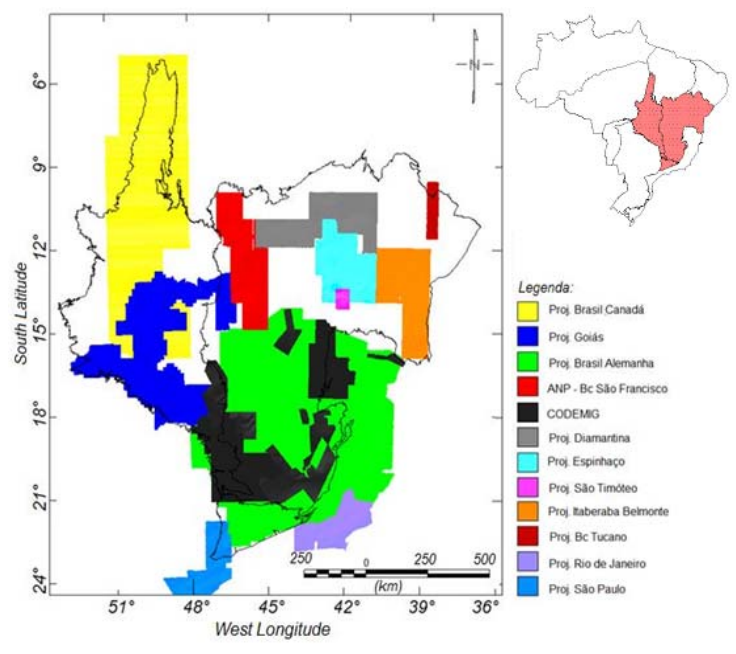

Figure (1) Geographic distribution of the areas covered aeromagnetic surveys in the present work.

\section{Aeromagnetic Data Analysis}

The aeromagnetic data sets were corrected initially for the effects of lag and heading. In addition, corrections for leveling and microleveling were also made and the anomalous component of the magnetic field determined by removing the main reference magnetic field and effects of external disturbances. The results obtained indicate that the residual anomalies in the study area are in the range of $+/-120 \mathrm{nT}$. A magnetic high is present in the central part of the study area known as the Iron Quadrangle. Other prominent anomalies include the broad region of high intensity in the Diamantina region. In 
addition, several small scale anomalies are present along the western border of the study area.

\section{Determination of Depths of Curie Temperatures}

The model adopted in the present work for mapping depth of Curie temperatures is based on the assumption that the anomalies in the observed crustal field is produced by distributed set of prismatic bodies. Spector \& Grant (1970) argued that the slopes of logarithms of azimuthally averaged power spectra of magnetic anomalies from ensemble of simple sources are related to depths to top of the ensemble:

$$
|F(k)|^{2}=4 \pi^{2} C_{m}^{2}\left|\theta_{m}\right|^{2}\left|\theta_{f}\right|^{2} M_{0}^{2} e^{-2 k z_{t}}\left(1-e^{-|k|\left(z_{b}-z_{t}\right)}\right)^{2} S^{2}(a, b)
$$

where $F$ is the Fourier power spectrum, $k$ is wave number in cycles $/ \mathrm{km}, \mathrm{C}_{\mathrm{m}}$ is a constant, $\Theta_{\mathrm{m}}$ a factor related to magnetization direction, $\theta_{\mathrm{f}}$ a factor related to magnetic field direction, $M_{0}$ is magnetization, $z_{t}$ and $z_{b}$ are depths to top and bottom of magnetic sources and $S^{2}(a, b)$ a factor related to horizontal dimensions of sources. In the case of layered magnetization, the spectrum may have peaks related to thickness of the layers.

In spectral estimation methods for determining depths to the Curie temperature it is convenient to divide the area of magnetic survey into overlapping cells of sufficiently large size. An azimuthally averaged power spectrum is generated for each cell, which then is examined to estimate the depth to the top and bottom of the magnetic layer.

Bhattacharyya \& Leu (1975) proposed the slope approach

for determining centroid from $1 / \mathrm{k}$ spectra:

$$
G(k)=\frac{1}{k} F(k)
$$

This approach was used by Okubo et al. (1985) in their study of "Curie depth" in Kyushu, Japan. In this work it was suggested that centroid estimates could be derived from data windows as small as $40 \mathrm{~km} \times 40 \mathrm{~km}$. However, as pointed out by Ravat et al (2004) this can lead to estimates on shallow/intermediate layers and not the deepest layers.

Fedi et al. (1997) recognized that shape factor, $S^{2}$, in the Spector \& Grant (1970) equation has a power law form for specific source dimensions tested by them, such that:

$$
|F(k)|^{2} \propto k^{-2.9}
$$

A similar correction, $\mathrm{k}^{-\beta}$, can also be used for fractal magnetic source layers as shown by Bansal et al. (2011). The technique of Okubo et al. (1985) and Tanaka et al. (1999) was employed in data analysis of the present work. The centroid depth is calculated from the low wavenumber part of the scaled power spectrum as:

$$
\ln \left(P(k)^{1 / 2} / k\right)=A-|k| Z_{0}
$$

where $P(k)$ is the radially average power spectrum, $\mathrm{k}$ is the wave-number $(2 \pi / \mathrm{km}), A$ is a constant depending on the properties of magnetization and its orientation, and $Z_{o}$ is the centroid depth of magnetic sources. For the high wave-number part, the power spectrum can be related to the top of magnetic sources by a similar equation:

$$
\ln \left(P(k)^{1 / 2}\right)=B-|k| Z_{t}
$$

where $B$ is a constant; $Z_{t}$ is the depth to the top of the deepest magnetic sources. The depth of the bottom of magnetization $\left(Z_{b}\right)$ is:

$$
Z_{b}=2 Z_{0}-Z_{t}
$$

Energy Spectrum Computation: In the procedure adopted power density spectrum was calculated for each window. The advantage of the $2 \mathrm{D}$ power spectrum is that the depth of sources is easily determined from by measuring the slope of the energy (power) spectrum and dividing it by $4 \pi$. Once the depth to the top bound is estimated, it is fairly simple to use the radially averaged frequency-scaled power to estimate the centroid depth $\left(Z_{0}\right)$. The basal depth $\left(Z_{b}\right)$ is then obtained using equation (6). An example of power spectrum of a sub-region is shown in figure (2).

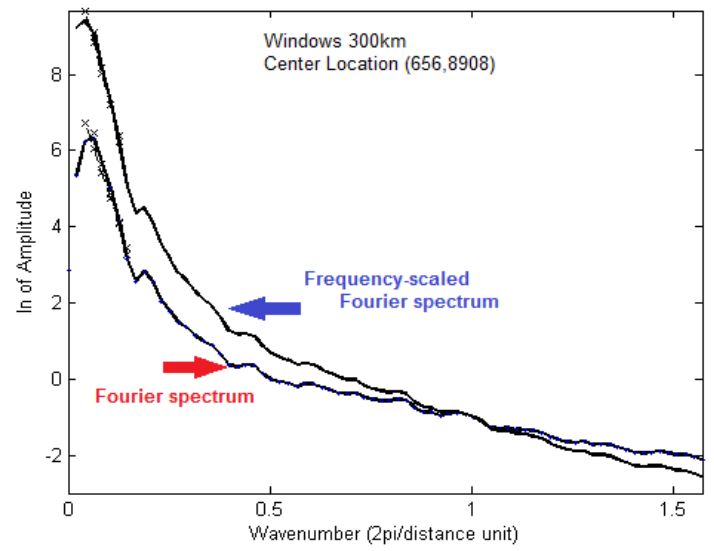

Figure (2) Power spectrum generated at the position of the center of grid cell at $-46.9^{\circ},-10.86^{\circ}$.

Selection of Crustal Segments: Three different segments of the crust were selected for analysis of the depths to top and bottom of magnetized crust in the study area. These are indicated in the map of Figure (3).

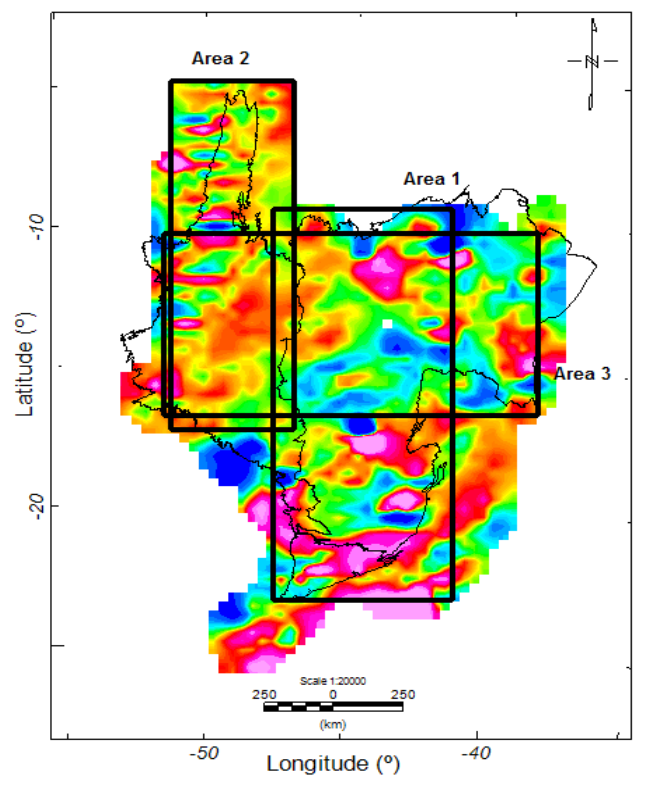

Figure (3) Crustal blocks selected for study of depths of magnetized crust in the study area. 


\section{Model Results}

In applying model calculations it is assumed that the depths to the bottom of magnetic sources (DBMS) correspond to the position of the Curie temperature of magnetite. Two different techniques were employed: designated here as the methods of Bhattacharya and Leu (1977) and Bansal et al (2011). Calculations were carried out for a total 54 overlapping crustal blocks in the study area.

The distribution of $D B M S$ values, derived by applying the procedure of Bhattacharya and Leu (1977), is presented in the map of Figure (4). It reveals substantial variations of $D B M S$ in the study area, with values in the range of 32 to $65 \mathrm{~km}$. DBMSs with values less than $44 \mathrm{~km}$ occur as isolated blocks lying roughly along a north - south trending belt. The main block is located in the southern part of the Tocantins province. Geologic units such as the Mineiro belt to the south and parts of Parnaiba basin, next to the northwestern part of the Tocantins province, also appear to have values of $D B M S$ less than $44 \mathrm{~km}$. Major crustal segments with values of $D B M S$ greater than $48 \mathrm{~km}$ are found to occur within the San Francisco structural province and also in the northern parts of the Tocantins province. There are indications that relatively large values of DBMS occur along a northwest - southeast trending belt in the study area. Intermediate values of DBMS, in the range of 42 to $46 \mathrm{~km}$, occur mostly in the eastern parts of the study area.

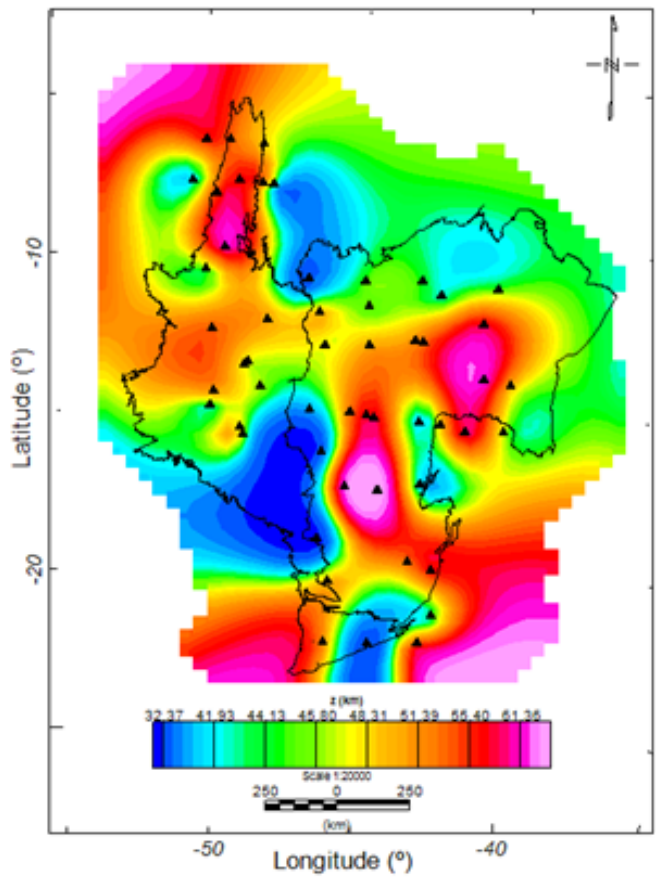

Figure (4) Map of DBMS values, derived by applying the procedure of Bhattacharya and Leu (1977). The points indicate centers of sampled windows.

The distribution of $D B M S$ values derived by applying the procedure of Bansal et al (2011) with $\beta=3$ is presented in the map of Figure (5). There are notable similarities in the main features of this map and those of Figure (4).

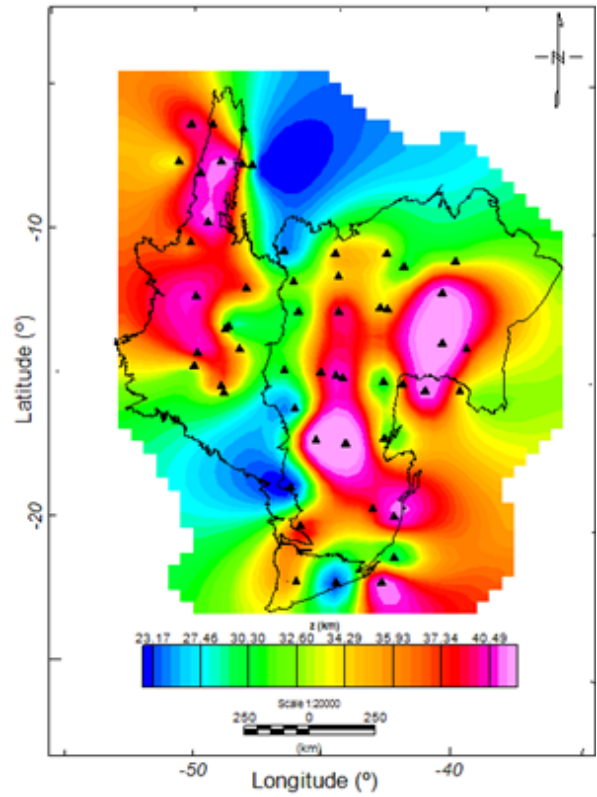

Figure (5) Map of DBMS values, derived by applying the procedure of Bansal et al (2011) with $\beta=3$. The points indicate centers of sampled windows.

The distribution of the values of depths to top of magnetic sources (DTMS), derived from applying the procedure of Bhattacharya and Leu (1977), or $\beta=0$, is presented in the map of Figure (6). Note that almost the entire area of the province of San Francisco have values of DTMS greater than $25 \mathrm{~km}$. Low to intermediate values occur mostly in the western border of the study area.

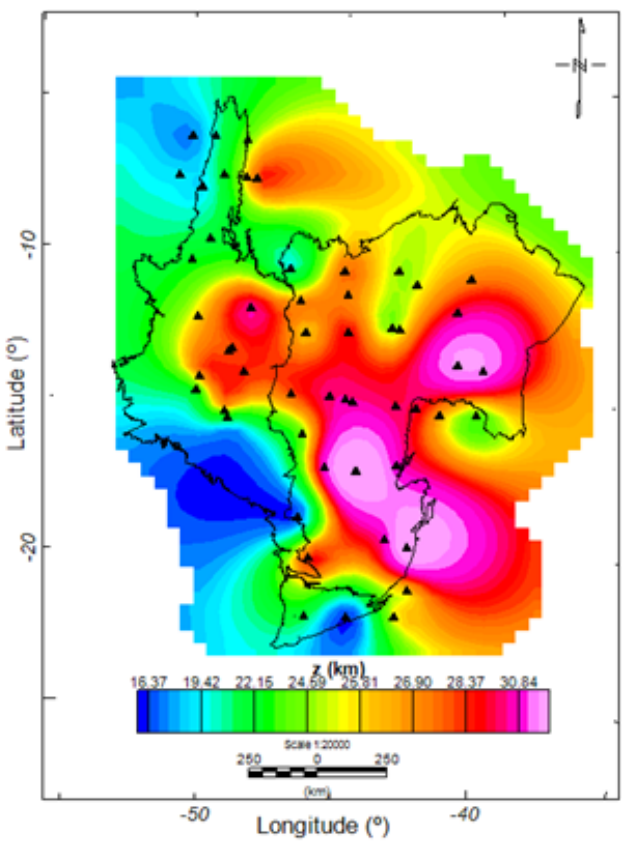

Figure (6) Map of the DTMS values, derived by applying the procedure of Bhattacharya and Leu (1977), or $\beta=0$. The points indicate centers of sampled windows. 
The distribution of the values of DTMS, derived from applying the procedure of Bansal et al (2011) with $\beta=3$, is presented in the map of Figure (7). In this case, the main difference is that the belt of high values of DTMS has shifted to the eastern border of the study area.

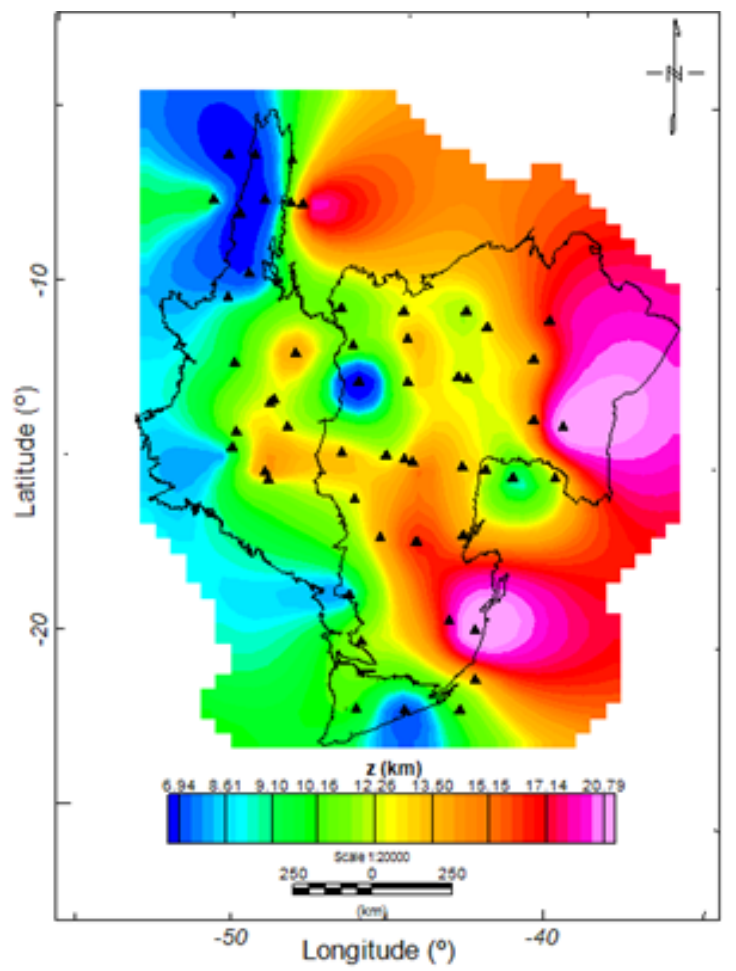

Figure (7) Map of the DTMS values, derived by applying the procedure of Bansal et al (2011) with $\beta=3$. The points indicate centers of sampled windows.

The effect of varying the window sizes of cells on the results obtained by the two methods are given in Table (1). It is clear that there is a significant difference, the method of Bansal et al (2011) producing values systematically lower than those obtained by Bhattacharyya and Leu (1977).

Table (1) Effect of varying the window size on the results obtained for the two methods.

\begin{tabular}{|c|c|c|c|c|c|c|}
\hline \multirow{2}{*}{ UTM } & \multicolumn{5}{|c|}{ Method Employed } & \multicolumn{2}{c|}{$\begin{array}{c}\text { Bhattacharyya } \\
\text { and Leu (1977) }\end{array}$} & \multicolumn{2}{c|}{$\begin{array}{c}\text { Bansal et al } \\
(2011) \text { with } \beta=3\end{array}$} & $\begin{array}{c}\text { Window } \\
\text { size }\end{array}$ \\
\hline x & y & Top & Bottom & Top & Bottom & \\
\hline 1374 & 7620 & 20.7 & 31.73 & 12.43 & 23.46 & 100 \\
\hline 1372 & 7620 & 27.63 & 44.23 & 13.13 & 25.64 & 200 \\
\hline 1374 & 7778 & 40.79 & 60.12 & 26.29 & 45.62 & 200 \\
\hline 1290 & 7806 & 29.37 & 50.93 & 17.4 & 37.24 & 300 \\
\hline 1186 & 8058 & 40.82 & 82.71 & 19.48 & 64.15 & 400 \\
\hline 1188 & 8058 & 41.62 & 69.01 & 14.94 & 40.73 & 500 \\
\hline 1012 & 7742 & 31.09 & 51.06 & 12.41 & 40.74 & 200 \\
\hline 974 & 7890 & 14.09 & 27.69 & 7.62 & 17.61 & 200 \\
\hline
\end{tabular}

It is convenient to note that calculation procedures for estimating the depths to Curie temperatures may have errors of the order of 10 to $20 \mathrm{~km}$.

\section{Discussion and Conclusions}

It is clear that the results obtained in the methods of analysis of Bhattacharya and Leu (1977) as well as Bansal et al (2011) point to the existence of significant variations in the depths of the Curie isotherm in the study area. The range of variation is 30 to $60 \mathrm{~km}$, with higher values occurring mostly in the structural province of San Francisco. The tectonic implications of this variation can be better understood by examining the depth variations of Curie isotherm in areas where crustal seismic studies have been carried out. The profiles selected for comparison of depths of Curie isotherm and crustal thickness is indicated in Figure (8).

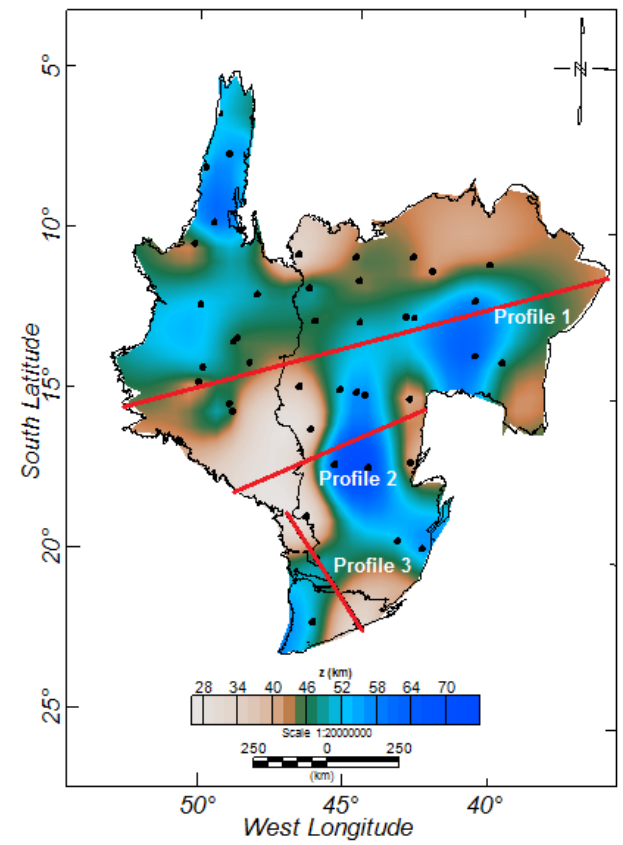

Figure (8) Map of depth to Curie isotherm and the profiles (red dots) selected for comparative analysis with crustal thickness.

The results obtained for the three profiles are illustrated in Figure (9) where red colored lines indicate crustal thicknesses determined in seismic studies (SCT) and the green lines indicate estimates of depths to Curie isotherm derived from spectral analysis of aeromagnetic data $(A D C)$ in the present work.

Comparative analysis of the thickness variations along the profiles reveals several interesting features. For example, values of SCT are lower than the values of $A D C$ along profile 1 in the Tocantins province. However the same is not true in profiles 2 and 3 .

$A D C$ values point to a pronounced peak in the interior of San Francisco province, probably an indication of the cold cratonic root in its central parts. Another important result is that the values of $A D C$ are systematically higher than those of $S C T$ in the San Francisco province, along profiles 1, 2 and 3 . This is an indication that magnetized layer extends to depths greater than those determined by seismic methods in cratonic areas. Usually seismic methods are good in identifying contrasts in acoustic impedance, but lack resolution for identifying changes in magnetic properties deep crustal layers. 

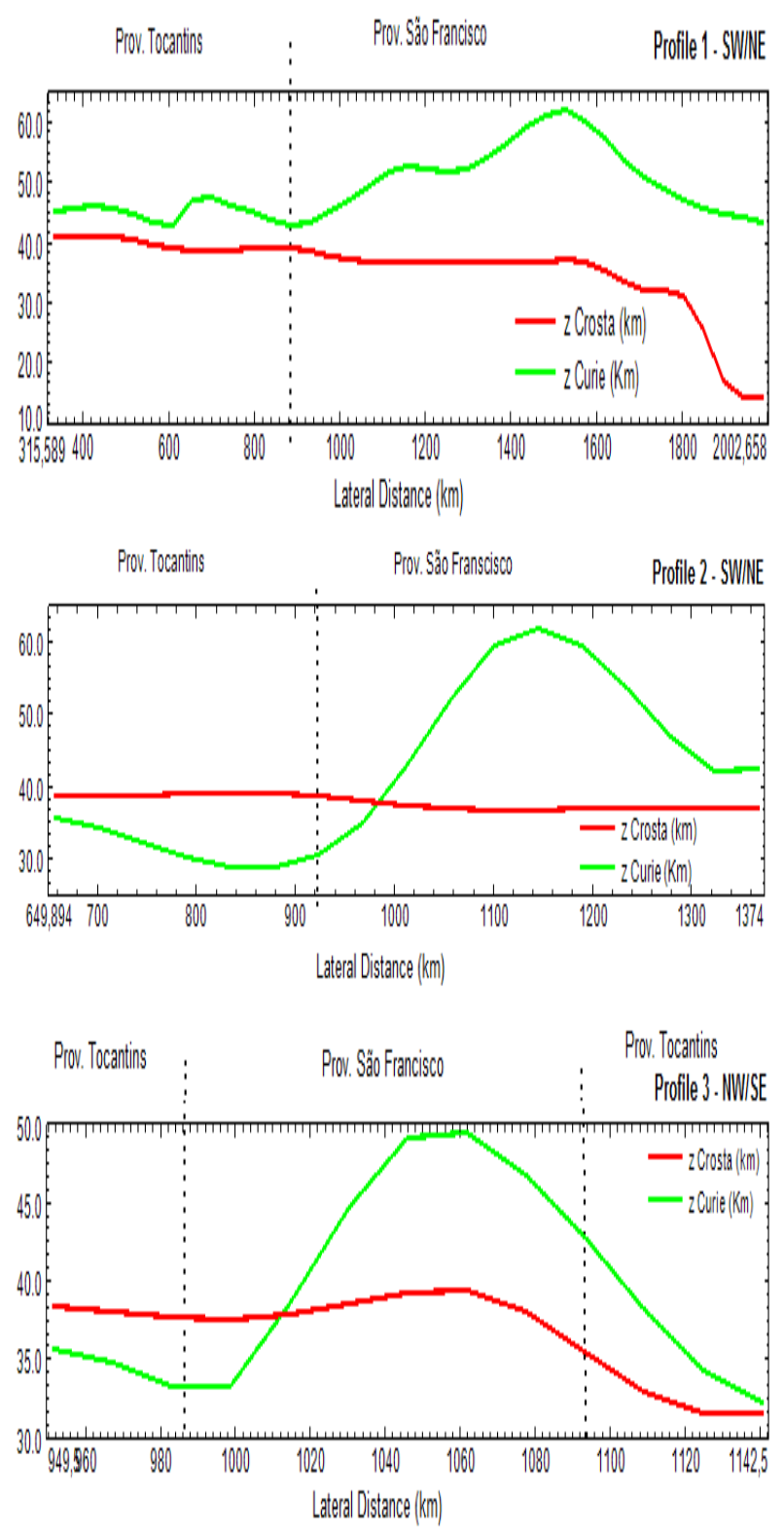

Figure (9) Crustal thicknesses and depths to Curie isotherm, along the three profiles selected in the present work.

\section{Acknowledgements}

Permission to use the data discussed in the present work was granted by CPRM, CNEN, SGM-GO, CODEMIG, ANP and ON. The first author of this work is recipient of a scholarship granted by CAPES. Computer programs developed at the Dept. of Earth and Environmental Sciences of the University of Kentucky were used in spectral analysis of aeromagnetic data.

Financial support provided by Fundação Amparo á Pesquisa do Estado do Rio de Janeiro - FAPERJ, for the project "Caracterização Físico-Química das Emanações provenientes das Falhas Geológicas na área Costeira do Estado do Rio de Janeiro" (Processo No. E-26/ $111.342 / 2010$ ) has been employed for field works.

\section{References}

ALLDREDGE, L.R. \& VAN VOORHIS, G.D. 1961. Depth to sources of magnetic anomalies. J. Geophys. Res., 66:3793-3800.

ALEXANDRINO C.H. e HAMZA V.M., 2008. Estimates of heat flow and heat production and a thermal model of the São Francisco Cráton. International Journal of Earth Sciences. v.97(2), 289-306.

ARKANI-HAMED, J. \& STRANGWAY, D.W. 1985. Lateral variations of apparent magnetic susceptibility of lithosphere deduced from Magsat data. J. Geophys. Res. 90:2655-2664.

ASSUMPÇÃO, M., An, M., BIANCHI, M., FRANÇA, G., ROCHA, M., BARBOSA, J.R. and BERROCAL, J. 2004. Seismic studies of the Brasilia Fold Belt at the western border of the São Francisco Craton, central Brazil, using receiver function, surface wave dispersion, and teleseismic tomography. Tectonophysics, 388:173-185.

BANSAL A. R., GABRIEL G.,DIMRI V. P. and KRAWCZYK C. M. 2011. Estimation of depth to the bottom of magnetic sources by a modified centroid method for fractal distribution of sources: An application to aeromagnetic data in Germany. Geophysics, Vol.76, N. 3, P. L11-L22.

BERROCAL, J., MARANGONI, Y., CÔGO DE SÁ, N., FUCK, R.A., SOARES, J.E.P, DANTAS, E., PEROSI, F. and FERNANDES, C. 2004. Deep seismic refraction and gravity crustal model and tectonic deformation in Tocantins Province, Central Brazil. Tectonophysics, 388:187-199.

BHATTACHARYYA, B.K. \& LEU, L.K. 1975. Analysis of magnetic anomalies over Yellowstone National Park: mapping of Curie-point isothermal surface for geothermal reconnaissance. J. Geophys. Res., 80:4461-4465.

BHATTACHARYYA, B.K. \& LEU, L.K. 1977. Spectral analysis of gravity and magnetic anomalies due to rectangular prismatic bodies. Geophysics, 42:41-50.

BHATTACHARYYA, B.K. \& MORLEY, L.W. 1965. The delineation of deep crustal magnetic bodies from total field aeromagnetic anomalies. J. Geomag. and Geoelec., $17: 237-252$.

BLAKELY, R., 1988. Curie temperature isotherm analysis and tectonic implications of aeromagnetic data from Nevada, J. geophys. Res., 93, 11 817-11832.

BLUM, M.L.B. \& PIRES, A.C.B. 1995. Determinação de superfície Curie: região central de Goiás. In: CONGRESSO INTERNACIONAL SOC. BRAS. GEOF., 4, Rio de Janeiro, 1995. Anais... Rio de Janeiro, SBGf, v.2, p.240-243.

BULINA, L.V. 1961. The use of airborne magnetic prospecting data in deep-seatted structure of the Earth's crust within the Siberian Platform. Sovetskaya Geol. 5:134-138. 
CHIOZZI, P., MATSUSHIMA, J., OKUBO, Y., PASQUALE, V. \& VERDOYA, M., 2005. Curie-point depth from spectral analysis of magnetic data in centralsouthern Europe, Phys. Earth planet. Int., 152, 267-276.

CONNARD, G., COUCH, R. \& GEMPERLE, M., 1983. Analysis of aeromagnetic measurements from the Cascade Range and in central Oregon, Geophysics, 48, 376-390.

HAMZA V.M. \& Muñoz M. 1996 Heat flow map of South America. Geothermics. V.25. Issue 6. p.599-621 - 623646.

FEDI, M., QUARTA, T. and DE SANTIS, A., 1997. Inherent power-law behavior of magnetic field power spectra from a spector and grant ensemble. Geophysics 62, 1143-1150.

FRANÇA G.S.L.A. de. 2003. Estrutura da Crosta no sudeste e centro-oeste do Brasil, usando função do receptor Local: São Paulo. Tese (doutorado). IAG/SP. $143 p$.

GASPARINI, P.; MANTOVANI, M.S.M.; CORRADO, G. \& RAPOLLA, A. 1979. Depth of Curie temperature in continental shields: a compositional boundary? Nature, 278:845-846

HALL, D.H. 1974. Long-wavelength aeromagnetic anomalies and deep crustal magnetization in Manitoba and northwestern Ontario, Canada. J. Geophys. 40:403430.

MAUS, S. \& DIMRI, V., 1995. Potential field power spectrum inversion for scaling geology, J. geophys. Res., 100,12 605-616.

MOONEY W.D., LASKE G. and Masters T.G. 1998. CRUST 5.1: A global crustal model at 5x5, J.Gephys.Res, v.103, B1, 727-747 In: VIEIRA F.P. 2010 Representaçao Global do fluxo de Calor Matélico. Dissertaçao de Mestrado - ON/MCTI.

NAGATA, T. 1961. Rock Magnetism. Maruzen Co., Ltd., Tokyo, Revised Edition, 350p

SEARSON, P.H. \& HANNAFORD, W.L.W. 1957. A statistical analysis of magnetic profiles. J. Geophys. Res., 62:1-18.

OKUBO, Y., GRAF, R.J., HANSEN, R.O., OGAWA, K.\& TSU, H., 1985. Curie point depths of the island of Kyushu and surrounding areas, Japan, Geophysics, 53, 481-494.

PILKINGTON, M. \& TODOESCHUCK, J.P., 1993. Fractal magnetization of continental crust, Geophys. Res. Lett., $20,627-630$.

RAVAT, D. PIGNATELLI, A. NICOLOSI, I \& CHIAPPINI, M. 2007 A study of spectral methods of estimating the depth to the bottom of magnetic sources from near- surface magnetic anomaly data. J.Int.Geophysics, 169, $421-434$.

SPECTOR, A. \& GRANT, F.S. 1970. Statistical models for interpreting aeromagnetic data. Geophysics, 35(2):293-302.

SHUEY, R.T., SCHELLINGER, D.K., TRIPP, A.C.\& ALLEY, L.B., 1977. Curie determination from aeromagnetic spectra, Geophys. J. R. astr. Soc., 50, 75101.

TANAKA, A., OKUBO,Y.\& MATSUBAYASHI,O., 1999. Curie point depth based on spectrum analysis of magnetic anomaly data in East and Southeast Asia, Tectonophysics, 306, 461-470.

VITORELLO I. \& POLLACK H.N. 1980 On the variation of continental heat flown with age and the thermal evolution of continents. J.of Geophysical Research. v.85, p.983995.

VACQUIER, V. \& AFFLECK, J. 1941. A computation of the average depth to the botton of the Earth's crust, based on astatistical study of local magnetic properties. Trans. Amer. Geophys. Union, 446-450. 